\title{
Rapid Realist Review of School-Based Physical Activity Interventions in 7- to 11-Year-Old Children
}

\author{
Emmanuel Defever ${ }^{1}$ (D) and Michelle Jones ${ }^{2, *(D)}$ \\ 1 Health and Social Sciences, Faculty of Sport, Southampton Solent University, Southampton SO14 0YN, UK; \\ e.t.defever@gmail.com \\ 2 Resilience and Human Performance Research and Knowledge Exchange Group, Plymouth Marjon University, \\ Plymouth PL6 8BH, UK \\ * Correspondence: mjones@marjon.ac.uk
}

check for updates

Citation: Defever, E.; Jones, M. Rapid Realist Review of School-Based Physical Activity Interventions in 7to 11-Year-Old Children. Children 2021, 8, 52. https://doi.org/ $10.3390 /$ children 8010052

Received: 27 November 2020 Accepted: 14 January 2021 Published: 16 January 2021

Publisher's Note: MDPI stays neutral with regard to jurisdictional claims in published maps and institutional affiliations.

Copyright: (C) 2021 by the authors. Licensee MDPI, Basel, Switzerland. This article is an open access article distributed under the terms and conditions of the Creative Commons Attribution (CC BY) license (https:// creativecommons.org/licenses/by/ $4.0 /)$.

\begin{abstract}
Meta-analysis of physical activity interventions in school settings have revealed low efficacy and that there is a need to explore implementation fidelity. The aim of this rapid realist review was to determine, what physical activity interventions in school settings for children aged 7- to 11-yearsold works, for whom, and in what circumstances. The realist synthesis was conducted following RAMESES guidelines. Relevant studies were identified following a systematic search process and data from 28 studies was extracted for evidence to form context-mechanism-outcome configurations that were clustered and refined. Using the five-level socioecological model, the program theories were classified into the levels of intrapersonal (child), interpersonal (teachers), institutional (program content, school administration, and school environment), community (home and neighborhood), and policy. The school level led to most context-mechanism-outcome configurations related to school leadership and policy, workforce structure, program characteristics, and school environment. At each level, we identified features of interventions, alongside implementation considerations that might work to promote efficacy and sustainability. The need to recognize the school environment as part of a complex system with multi-level interaction and influences was a key finding. In line with realist philosophy, the researchers encouraged primary research to confirm, refute, and refine the program theories presented.
\end{abstract}

Keywords: physical activity; school setting; socioecological model; intervention; realist synthesis

\section{Introduction}

Physical activity is associated with physiological, developmental, mental, cognitive, and social health benefits in young people [1-3]. Consequently, recently updated global physical activity guidelines recommend children aged 5 to 17 years engage in an average of $60 \mathrm{~min}$ a day of moderate-to-vigorous physical activity [4]. It has been estimated that approximately $80 \%$ of young people worldwide do not meet these physical activity guidelines [5]. Recent evidence suggests a decline in physical activity from early childhood [6-8]. For example, a cross-sectional study incorporating 10 countries identified an annual decrease of $4.2 \%$ moderate-to-vigorous physical activity after 5 years of age [7]. It is therefore imperative to promote physical activity and intervene early in childhood prior to the decline in physical activity. Children compulsorily spend $40 \%$ of their waking time at school [9] and the school setting provides a location for interface with all children and so is an ideal environment for population-based physical activity interventions [10].

Two recently published systematic reviews and meta-analysis of school-based interventions identified no significant effect size for daily moderate-to-vigorous physical activity across 17 randomized controlled trials in the 6- to 18-year-old age range [11] or a significant moderate effect for daily moderate-to-vigorous physical activity but with low precision and considerable inconsistency across 10 experimental studies in 5- to 11year-old children [12]. Current intervention approaches seem relatively ineffective at 
promoting whole day physical activity and thus it is timely to explore implementation fidelity [11,13]. Published systematic reviews provide limited insight into the complex causal pathways that may underpin intervention effectiveness [14] or mechanisms that explain how interventions and participants interact to produce observed outcomes [15]. Schools are complex social structures with unique qualities that can influence intervention fidelity and do not always allow for programs to be transferred from one school to another with predictable results [16]. A realist review explores causal mechanisms of intervention effects under different contextual circumstances and might provide new insights in terms of school-based physical activity interventions. For example, Brown et al. [14] conducted a dual meta-analysis and realist synthesis to understand the effectiveness of family-based physical activity interventions and a realist synthesis revealed novel insights including that interventions focusing on something other than the health benefits of physical activity or weight loss, such as improving quality family time, appeared to be an effective mechanism for changing physical activity behavior.

Realist methodology is a theory-driven approach that generates a set of program theories in context-mechanism-outcome (CMO) configurations to provide a scientific basis for the transferability of the theories developed and tested $[17,18]$. The realist methodology provides a means to deal with intervention heterogeneity and make inferences about context and effectiveness $[19,20]$. Realist reviews can complement what is already known from systematic reviews and supplement the knowledge by exploring underlying causalities [21]. There is relatively little information on the underlying mechanisms of change within school-based physical activity interventions; indeed, few studies have identified a theoretical framework to underpin intervention design. Existing intervention studies that describe a theoretical underpinning have typically identified social cognitive theories [22-26], whereas Beets et al. [27] suggested that interventions underpinned by behavioral theories are largely misplaced in assuming children are autonomous agents in their physical activity decision-making. A small number of studies reported designing interventions based on a social-ecological model that integrates intra- and inter-personal influences alongside the impact of the organization, community, and wider public policy [28-33]. Furthermore, there are some national frameworks for physical activity promotion within school settings that are typically multi-component and recognize levels of influence similar to the socioecological model, e.g., the Comprehensive School Physical Activity Program in the United States of America. The socioecological model was developed as an ecological model for health promotion, focusing on both individual and social factors and recognizing the dynamic interrelations among individual and environmental factors. As such, the socioecological model and realist methodology share similarities in that they recognize that behavioral change interventions can be messy and complex [34], with a multitude of interactions between stakeholders and the target population, all of whom share a certain context governed by policies.

A rapid realist review has the potential to inform the development of a conceptual framework by exploring intervention characteristics that generate observed changes (i.e., mechanisms). When the mechanisms are triggered under certain circumstances (i.e., context), they ultimately change the decision-making or behaviors of the target population (i.e., outcomes, intended or unintended) [35]. Exploring complex mechanisms that are often hidden can help researchers understand and explain observed outcomes (intended and unintended) within a phenomenon [36]. The rapid realist review can be seen a complementary analysis to systematic review and meta-analysis to explore the contexts that trigger certain mechanisms and the resultant outcomes that can be hidden within systematic reviews. The aim of this rapid realist review was to determine, within a socioecological model, what works, for whom, and in what circumstances for physical activity interventions in school settings for children aged 7- to 11-years. 


\section{Materials and Methods}

This rapid realist review is a complimentary analysis accompanying a published systematic review and meta-analysis that details the full methodology [12]. In brief, the review was registered with the prospective register of systematic reviews (PROSPERO, CRD42017082184). A literature search was conducted to identify peer-reviewed intervention studies of any methodological design that promoted physical activity in school settings in children aged 5 to 11 years. A structured electronic bibliographic search of five databases (ERIC, MEDLINE, PsychINFO, SPORTDiscus, and Web of Science) was used to retrieve articles published in the English language through 30 June 2017. The search strategy combined multiple keyword search terms agreed to a priori. The search terms focused on 4 key elements: (1) outcome measure; (2) study population; (3) study type; and (4) setting. A two-step screening process was used to determine whether each study met the inclusion criteria. Studies were included if they: (1) involved children of primary/elementary/middle school age, e.g., 5- to 11-years-old; (2) reported on an intervention that lasted at least 4 weeks, was implemented within a school environment, and was targeted at physical activity; and (3) reported an objectively assessed measure of physical activity. Following title and abstract screening of 1115 records, the removal of duplicates $(n=584)$ and articles that did not meet the inclusion criteria $(n=419)$ resulted in 112 studies remaining. Two independent reviewers assessed the full text of the remaining 112 studies against the inclusion criteria, resulting in a further 52 studies' being excluded. The systematic review, therefore, included 57 original studies. The quality of the included studies was assessed by two independent reviewers using the mixed methods appraisal tool [37], which has content-validity for each domain. Items were developed from the literature, as were consultations and workshops with experts [37-39].

This rapid realist review was conducted using the RAMESES quality and publication guidelines for realist synthesis [21]. The literature was synthesized to derive the hypothesized context and mechanisms necessary to elicit a specified outcome. Data extraction (e.g., verbatim sections of text) for the review included "gleaning stages" conducted initially by one reviewer (ED) and then confirmed/challenged by a second (MJ) until consensus was reached. Each of the full-text studies was reviewed for any evidence, description, or insight contributing to forming either full or partial $\mathrm{CMO}$ configurations and focused specifically on those articles that included children in the 7- to 11-year-old age range as participants. A total of 28 full-text articles provided sufficient information to describe outcome patterns and thus contributed to the realist rapid review. The relevant information was extracted verbatim and grouped into clusters of similar topics. Where appropriate, theories cited in the included interventions were noted to provide additional insight into possible or missing mechanisms. The second process included arranging the extracted verbatim into $\mathrm{CMO}$ configured statements. Within each cluster, $\mathrm{CMO}$ configurations were then distilled for conciseness and simplicity. The third gleaning involved mapping the CMO configurations for visual clarity within the levels of the socioecological model. Finally, the fourth process involved refining the CMO configurations to concisely reflect the evidence from included studies.

\section{Results}

\subsection{Description of Studies}

The study designs of the 28 studies included randomized controlled trials (RCT, $n=12$, $43 \%)$ [22,40-50], cluster RCTs $(n=5,18 \%)$ [23,24,51-53], non-randomized control studies $(n=8,29 \%)[25,29,54-59]$, and descriptive studies $(n=3,11 \%)$ [60-62]. Quality scores using the mixed methods appraisal tools ranged from $0 \%(n=5,18 \%)[23,45,46,49,50], 25 \%(n=2$, $7 \%$ ) [41,59], 50\% $(n=7,25 \%)[40,42,44,47,48,54,56], 75 \%(n=8,29 \%)[24,25,29,43,55,57,58,61]$, and $100 \%(n=6,21 \%)[22,51-53,60,62]$. Over half of the studies were published from 2011 onwards $(n=15,54 \%)$ [22-24,29,40,44-46,52,54,55,57,59-61], whereas 12 studies (43\%) were published between 2001 and 2010 [25,42,43,47-51,53,56,58,62] and one study was published before 2000 [41]. The interventions were conducted in the United States of 
America $(n=12,43 \%)[24,41,43-45,47,48,51,54,55,59,61]$, United Kingdom, Ireland $(n=8$, $29 \%$ ) $[22,25,40,49,50,56,58,60]$, other European zone countries (e.g., Belgium, Denmark, Iceland, the Netherlands, and Switzerland, $n=5,18 \%)[23,42,46,53,57]$, and Australia and New Zealand $(n=3,11 \%)[29,52,62]$.

Intervention duration ranged from four weeks to two years; 11 studies lasted for approximately one school term (up to 12 weeks or 3 months, $n=13,46 \%$ ) [22,24,29,40,42,44,47-49,55,58,60,62], seven studies (25\%) lasted between one term and one academic year [25,46,52-54,59,61], and six studies (21\%) lasted more than one academic year [23,41,43,45,51,57]. Two were longitudinal follow-up studies $[50,56]$. Interventions included a variety of approaches such as expanding, enhancing, or extending play time $(n=9,32 \%)[29,42,44-46,49,50,52,58]$, whole-school approaches $(n=8,29 \%)$ [23,25,41,53-56,59], classroom-based physical activity $(n=4,14 \%)[22,40,48,51]$, use of pedometer as an intervention tool $(n=3,11 \%)[47,60,62]$, physical education $(n=1,4 \%)$ [57], after-school activity $(n=1,4 \%)$ [43], active travel to and from school $(n=1,4 \%)$ [24], and school policy change $(n=1,4 \%)$ [61]. No detail of a theoretical framework was described for the intervention in a high proportion of studies $(n=17,61 \%)[40-42,44,46-52,54,57,58,60-62]$. Five studies (18\%) reported the application of social cognitive theory [23-25,43,56], three studies $(11 \%)$ reported intervention design around the socioecological model $[29,45,53]$, one study $(3 \%)$ reported use of a behavioral change model [22], one (3\%) reported theories of organizational change and innovation [55], and one reported an unspecified behavioral theory [59].

\subsection{Literature Derived Program Theories}

The studies demonstrated variation in the context within which interventions were conducted, the intervention strategies employed, and the mechanism targeted. Despite the heterogeneity of the intervention types, the studies contributed to generating an extensive list of initial program theories. The CMO configurations from each study were distilled to draw out patterns to explore insights into the architecture of school-based physical activity interventions.

Using the five-level socioecological model by McLeroy et al. [63], the list of initial program theories were classified into the levels of intrapersonal (i.e., child), interpersonal (i.e., teachers), institutional (i.e. program content, school administration, school environment), community (i.e., home and neighborhood), and policy. At an individual level (child), Table 1 summarizes the key $\mathrm{CMO}$ configurations that are primarily related to the use of pedometers, goal setting, and rewards. The context of how pedometers were implemented triggered different mechanisms and outcomes. Table 2 summarizes the key CMO configurations at an inter-personal level where the key context was the classroom teacher, training, resources, and involvement required by the teacher. Adequate training and resources triggered mechanisms that supported implementation fidelity of interventions. The institutional or school level led to the greatest number of $\mathrm{CMO}$ configurations. There were three sub-levels: program characteristics, school leadership and administration, and school environment. Table 3 summarizes the CMO configurations. In summary, the contexts that led to higher implementation fidelity and efficacy included school leadership support, limited impact on stretched resources, a workforce structure with dedicated physical activity staff, maximizing utilization of the school playground with trained workforce, and approaches to non-controllable factors such as adverse weather. In comparison, ineffective or inconsistent implementation and program outcomes typically occurred when time and resources were stretched and there was no school leader support, especially when training for staff is not provided and workforce structures do not prioritize physical activity. There were relatively few CMO configurations at the community and policy level, as summarized in Table 4. This reinforces the importance of parental support and the challenges of educational policy that prioritizes academic achievement. 
Table 1. Individual level (child) of a conceptual framework for school-based physical activity interventions in children aged

7-11 years of program theories (context-mechanism-outcome).

\begin{tabular}{cccc}
\hline Context & Mechanism & Outcome & Supporting Evidence \\
\hline $\begin{array}{c}\text { If pedometers are used to set } \\
\text { whole class targets (goal } \\
\text { setting) and a celebration } \\
\text { event is provided. }\end{array}$ & $\begin{array}{c}\text { Then pedometers encourage } \\
\text { inter-class competition and create } \\
\text { social support. }\end{array}$ & $\begin{array}{c}\text { Positive influence on } \\
\text { individual behavior and } \\
\text { leads to increased daily } \\
\text { step count. }\end{array}$ & $\begin{array}{c}\text { Gorely et al. [25] } \\
\text { Oliver et al. [62] }\end{array}$ \\
$\begin{array}{c}\text { If pedometers are used as a } \\
\text { self-monitoring device } \\
\text { (individual goal setting). }\end{array}$ & $\begin{array}{c}\text { Then pedometers provide a } \\
\text { physical activity currency, which } \\
\text { is popular especially for those } \\
\text { children with low initial physical } \\
\text { activity as it motivates children. }\end{array}$ & $\begin{array}{c}\text { Raised awareness of } \\
\text { physical activity and } \\
\text { increased step count. } \\
\text { But, there is a ceiling effect } \\
\text { for children with high } \\
\text { baseline physical activity. }\end{array}$ & Kang and Brinthaupt [47] \\
\hline $\begin{array}{c}\text { If pedometers are used } \\
\text { without a rewarding system. }\end{array}$ & $\begin{array}{c}\text { Then younger children resent the } \\
\text { burden and do not understand } \\
\text { goal setting. }\end{array}$ & $\begin{array}{c}\text { Ineffective individual } \\
\text { behavior change and no } \\
\text { increase in physical activity. }\end{array}$ & Burns et al. [54] \\
\hline
\end{tabular}

Table 2. Interpersonal level (class teacher) of a conceptual framework for School-Based Physical Activity Interventions in Children Aged 7-11 Years of program theories (context-mechanism-outcome).

\begin{tabular}{|c|c|c|c|}
\hline Context & Mechanism & Outcome & Supporting Evidence \\
\hline $\begin{array}{c}\text { If teacher training } \\
\text { workshops are provided. }\end{array}$ & $\begin{array}{l}\text { Then teachers become } \\
\text { empowered and increase } \\
\text { delivery confidence and } \\
\text { competence. Teachers feel a } \\
\text { sense of autonomy and } \\
\text { ownership over the program. }\end{array}$ & $\begin{array}{l}\text { Teachers model positive } \\
\text { physical activity behavior and } \\
\text { there is high program } \\
\text { implementation fidelity and } \\
\text { increased child } \\
\text { physical activity. }\end{array}$ & $\begin{array}{l}\text { Magnusson et al. [23] } \\
\text { Donnelly et al. [51] }\end{array}$ \\
\hline $\begin{array}{l}\text { If physical activity resources } \\
\text { and equipment are provided } \\
\text { without training. }\end{array}$ & $\begin{array}{c}\text { Then teachers lack autonomy } \\
\text { and perceive physical activity } \\
\text { program delivery as a } \\
\text { stand-alone and additional. }\end{array}$ & $\begin{array}{l}\text { Teachers do not use, or misuse } \\
\text { the resources provided. }\end{array}$ & $\begin{array}{l}\text { Huberty et al. [45] } \\
\text { Martin and Murtagh [22] } \\
\text { Weaver et al. [59] }\end{array}$ \\
\hline $\begin{array}{c}\text { If the intervention requires } \\
\text { substantial } \\
\text { teacher involvement, }\end{array}$ & $\begin{array}{l}\text { Then there will be a differential } \\
\text { response depending upon } \\
\text { willingness and } \\
\text { training provided. }\end{array}$ & $\begin{array}{c}\text { Ineffective and/or } \\
\text { inconsistent implementation } \\
\text { of the physical } \\
\text { activity program. }\end{array}$ & $\begin{array}{c}\text { Drummy et al. [40] } \\
\text { Huberty et al. [45] } \\
\text { Martin and Murtagh [22] } \\
\text { Weaver et al. [59] }\end{array}$ \\
\hline
\end{tabular}

Table 3. Institutional level (school) of a conceptual framework for School-Based Physical Activity Interventions in Children Aged 7-11 Years of program theories (context-mechanism-outcome).

\begin{tabular}{|c|c|c|c|}
\hline Context & Mechanism & Outcome & Supporting Evidence \\
\hline $\begin{array}{l}\text { If the school leadership } \\
\text { implement changes to } \\
\text { school level policy to } \\
\text { support physical activity. }\end{array}$ & $\begin{array}{l}\text { Then teachers see the high-level } \\
\text { support which increases } \\
\text { importance of physical activity } \\
\text { and enables a whole } \\
\text { school approach. } \\
\text { But, when there are competing } \\
\text { academic demands and reduction } \\
\text { in high level support. }\end{array}$ & $\begin{array}{c}\text { Effective implementation and } \\
\text { increased child } \\
\text { physical activity. } \\
\text { The Physical activity program } \\
\text { loses support and } \\
\text { implementation fidelity is low. }\end{array}$ & Gorely et al. [25] \\
\hline $\begin{array}{l}\text { School based resources are } \\
\text { stretched, and time is } \\
\text { limited. If the physical } \\
\text { activity program } \\
\text { characteristics require } \\
\text { school resources. }\end{array}$ & $\begin{array}{l}\text { Then a low cost and set up that is } \\
\text { easy to deliver within the } \\
\text { stretched resource base. } \\
\text { But, if higher costs / time is } \\
\text { required the program is viewed as } \\
\text { impractical and no time } \\
\text { to implement. }\end{array}$ & $\begin{array}{l}\text { Higher implementation of the } \\
\text { program and increased child } \\
\text { physical activity. } \\
\text { Ineffective and/or } \\
\text { inconsistent implementation } \\
\text { of the physical } \\
\text { activity program. }\end{array}$ & $\begin{array}{c}\text { Kang and Brinthaupt [47] } \\
\text { Gorely et al. [56] } \\
\text { Holt et al. [61] }\end{array}$ \\
\hline
\end{tabular}


Table 3. Cont.

\begin{tabular}{cccc}
\hline Context & Mechanism & Outcome & Supporting Evidence \\
\hline $\begin{array}{c}\text { If the school workforce } \\
\text { structure includes a } \\
\begin{array}{c}\text { dedicated staff position for } \\
\text { physical activity. }\end{array}\end{array}$ & $\begin{array}{c}\text { Then it increases the chance of } \\
\text { program sustainability and } \\
\text { continuity }\end{array}$ & $\begin{array}{c}\text { Program implementation, } \\
\text { delivery and maintenance are } \\
\text { improved. }\end{array}$ & Burns et al. [54] \\
\hline
\end{tabular}

If the characteristics include structure and adult supervision of physical activity (e.g., active learning, formal playtime program).

But if the characteristics of the program is unstructured physical activity (e.g., increased recess time or free play equipment).

If the school playground environment is maximized including staggered lunch times and sectioning areas for specific activities.

But if the school playground is supervised but otherwise not managed.

And if training is provided for playground supervisors.

But if training is not provided for playground supervisors during an intervention.

If the school has approaches related to adverse non controllable factors such as adverse weather.
Then the whole class/group engages with the program. But the program will stop when the formal intervention stops.

Then it stimulates creativity and child autonomy increases with more self-directed physical activity.
Children are happy to participate and certain groups, especially girls, increase their physical activity during the intervention. But this is not maintained beyond the

formal intervention.

More sustained increases in child physical activity and PA maintains challenge.
Dzewaltowski et al. [43] Ridgers et al. [49] and [50] Efrat [44]

Hyndman et al. [29] Engelen et al. [52]
Then girls are more likely to occupy play spaces they normally do not and there is an increased choice of physical activity.

Then certain spaces remain occupied by specific groups and there are dominant play characteristics (e.g., football).

Then supervisors initiate activities and increase use of play equipment.

The intervention can be seen as interference with a chance to socialize among staff
Reduced gender differences in physical activity and overall increased child physical activity.

Janssen et al. [46] Ridgers et al. $[49,50]$

Differential intervention outcomes (e.g., of increased play time) by age and gender, older children may reduce physical activity.

Sustained stimulus for physical activity and increased child physical activity.

Intervention program loses support and low

implementation fidelity.
Janssen et al. [46]

Ridgers et al. [49]

Gorely et al. [25]

Huberty et al. [45]
Then alternative indoor classroom physical activity can take place and disruption is minimized.
Physical activity is sustained and unaffected by adverse weather.
Martin and Murtagh [22]

Table 4. Community and policy level of a conceptual framework for School-Based Physical Activity Interventions in Children Aged 7-11 Years of program theories (context-mechanism-outcome).

\begin{tabular}{cccc}
\hline Context & Mechanism & Outcome & Supporting Evidence \\
\hline $\begin{array}{c}\text { If parental support is not } \\
\text { established for physical } \\
\text { activity intervention. }\end{array}$ & $\begin{array}{c}\text { Then parents consider a } \\
\text { cost-benefit analysis and } \\
\text { many have low self-efficacy to } \\
\text { engage with the program. }\end{array}$ & $\begin{array}{c}\text { Ineffective implementation } \\
\text { and or inconsistent outcomes } \\
\text { on child physical activity. }\end{array}$ & $\begin{array}{c}\text { Mendoza et al. [24] } \\
\text { Gorely et al. [56] } \\
\text { Oliver et al. [62] }\end{array}$ \\
$\begin{array}{c}\text { Then teachers focus on } \\
\text { If education policy prioritizes } \\
\text { academic attainment. }\end{array}$ & $\begin{array}{c}\text { academic achievement and if } \\
\text { the program does not support } \\
\text { academic attainment. }\end{array}$ & $\begin{array}{c}\text { Ineffective implementation of } \\
\text { physical activity. }\end{array}$ & $\begin{array}{c}\text { Kang and Brinthaupt [47] } \\
\text { Gorely et al. [56] } \\
\text { Holt et al. [61] }\end{array}$ \\
\hline
\end{tabular}




\section{Discussion}

\subsection{Intrapersonal Level: Child}

At an individual level, the main strategy implemented was goal setting that was typically at a class-level as opposed to individual target setting [25,54,62]. This type of goal setting seemed to shift the sense of success or failure from individuals to the whole class, as a team, which in turn created a positive social and peer supportive environment that led to increased physical activity $[25,54,56]$. In relation to the question of what works and for whom, goal setting seemed to lead to different outcomes dependent upon group characteristics. One study reported a differential response to a virtual walk challenge, finding that only those with lower initial physical activity significantly increased physical activity, especially girls [62]. Another study reported that a goal setting daily step challenge led to a differential response based on age with grade 3 children ( 8 to 9 years) experiencing a significant reduction physical activity in contrast to grade 6 children (11 to 12 years) who significantly increased physical activity [54]. It was speculated that children in the younger age range do not have sufficient autonomy to make their own life choices independently, as parents have the overall responsibilities in shaping their behavior. A child participant in Gorely et al. [56] (p. 9) commented that "most of the time (she was) not allowed to run around and do things because (her) mum wants to keep (her) safe." These interactions influence child behavior and are reflected in the community level CMO configurations. Younger children may be hampered or encouraged to apply their newly acquired behavioral change skills outside the school environment dependent upon parental influence [64,65]. This differential response highlights the weakness of methods of statistical analysis that aggregate findings. The headline program theory suggests goal setting at the class level may be an effective aspect of physical activity programs in older children (10-11 years) and especially in those with low initial fitness.

\subsection{Interpersonal Level: Teacher}

The main stakeholder at the interpersonal level of the socioecological model was the class teacher and the overarching mechanisms related to the teachers perceived autonomy and empowerment to facilitate physical activity. Class teachers are crucially positioned in the school-based intervention as "agents of change" [66]. Presenting teachers with interventions that fit with their schedules, curriculum, and beliefs/values about teaching is important for successful implementation [67]. When implemented in a way that triggers positive response mechanisms, class teachers delivered physical activity interventions that led to increased physical activity, including stand-alone class physical activity breaks $[40,48,61]$, physically active learning [22], or class physical activity breaks as part of a multi-component program [23,25,59]. McMullen et al. [68] identified three main factors that contributed to teachers adopting a physical activity program; 1 ) the need for classroom control, 2) a preference for physical activity integration with connections to academic content, and 3) the importance of implementation ease and student enjoyment.

The CMO configurations suggested several critical implementation factors, i.e., the initial training and whether this adequately covered the concept, purpose, and requirements of program delivery, as well as the level of autonomy the teacher was permitted by the program to fit around their normal teaching routine. The ability of the teacher to tailor and adapt the program contributes to teacher compliance and their positive receptiveness towards physical activity promotion [22,25,40,69]. If teachers are empowered and autonomous then they are likely to implement the program with high fidelity; this in turn creates a cyclic positive chain reaction whereby children enjoy physically active lessons. Some studies reported additional benefits such as increased time on tasks subsequent to the class' physical activity breaks [48]. In contrast, if teachers were not provided with adequate training or resources, then the intervention was perceived as a stand-alone and teachers were disempowered to implement the program due to little sense of ownership; this resulted in low fidelity or no uptake of the program. In the current climate of educational policy where academic achievement is typically prioritized, any delivery of interventions 
with no directly perceived impact on academic targets must conform within the frameworks that demand performance outcomes [70]. Teachers can feel overwhelmed with the amount of teaching that has to be covered in a single day, let alone having the capacity to even consider implementing physical activity programs on top of this learning [61].

\subsection{Institutional Level: School}

The institutional level program theories were divided into three sub-levels: program characteristics, school leadership and administration, and school environment. The head teacher primarily constructs a school culture, but the requirement for the school to achieve high academic standards has a substantial influence on school culture. The emphasis on academic achievement creates barriers to teachers taking on responsibility for anything other than time devoted to core subjects [69]. As such, physical activity programs need to include designs that are low cost, cause minimal disturbance, and are adaptable to the existing school operational routine to have higher implementation fidelity [40,71]. Teachers can perceive delivery of health promotion programs as an additional responsibility and that they are likely to implement in a permissive culture. An interview of a head teacher in the study by Langille and Rodgers [72] (p. 887) commented that "it is just a matter of changing the culture to make sure that everybody thinks that (it is) an important thing to do and not interfering with their language arts lesson or their math lesson and so on and so forth." The school culture also impacts on the workforce structure; for example, employment of a physical activity specialist can result in children's perceived support and relevance of physical activity, resulting in potentially effective program implementation [54].

In terms of program characteristics, resource availability was an important context. The school setting has a finite availability of resources and when physical activity programs compete with already stretched school resources the program has low implementation fidelity $[47,56]$. However, if a physical activity program is set-up with low running costs and minimal resources required, then there is less disturbance and implementation of the program is feasible [40]. The characteristics of the program was another contextual factor grouped into whether the delivery was compulsory (e.g., classroom-based physical activity where participation is mandatory), structured (e.g., adult facilitated playtime, afterschool activities), or unstructured (child facilitated). Compulsory physical activity requires the whole class to participate and thereby was most likely to increase the physical activity of every child with high adherence $[22,53]$. Similarly, children willingly participate in structured physical activity as the responsibility of initiating, organizing, and resolving conflict during the activity is shifted to the facilitator and children can become passive recipients of the intervention [43]. The unintended outcome of compulsory and structured delivery is that when the organized activity is no longer available, the continuation of physical activity participation is jeopardized [53,56]. Alternately, unstructured physical activity opportunities encourage children to initiate, organize, and engage the activity leading to small but significant increases in physical activity $[29,52]$ and these responses can be supported by appropriate social prompting [44]. Children's creativity and physical/social development is stimulated by unstructured physical activity, which thus encourages self-directed physical activity $[29,52]$.

The environmental component at the institutional level of the socioecological model identifies ways in which schools can adapt the relatively un-modifiable physical environment to influence children's physical activity. For example, studies have altered the playground space either by staggering playtimes or installing markings and structures $[46,49,50,58]$. Staggering playtimes allows more space per child [50] and when the space is allocated for specific activities (e.g., designated zones for football and free play) it allows more space for other activities [46,49]. This type of space zoning disrupts the age-based hierarchy of space occupancy and also reduces gender differences in physical activity during play time [46]. The installation of playground markings or structures seems to require sustained stimuli to maintain children's motivation to stay active $[49,50]$. There was an interaction of the socioecological model between the institutional environment 
and interpersonal levels. Playtime supervisors or teachers on playtime duty impacted the outcomes of interventions. Training playtime supervisors by providing resources such as moveable equipment, game cards, and/or a monthly play theme seemed to act as a stimulus for increased physical activity $[45,46,50]$. In contrast, there was an unexpected response mechanism by teachers/supervisors who perceived playtime as a social time and chance to catch up with colleagues and thereby focused on the safety aspect only. This, naturally, led to lower implementation fidelity [45]. A final context identified was adverse weather including cold weather, lower daylight hours, and rain. However, support for classroom-based physical activity programs led to a response of maintenance of physical activity in the winter [22].

\subsection{Community and Policy Level}

Previous research has suggested that social support from parents does not mediate child physical activity behaviors [73,74]. Few studies have incorporated outreach components into school-based interventions perhaps due to reported difficulties engaging parents in physical activity programs [75]. Those studies including a home-based element have included activity-based homework $[25,56]$ and active travel [24]. Two studies did identify mechanisms in relation to parental support; one study that trebled PE curriculum time discovered an unintended parental response that out of school activity was not necessary [57] and another study identified parental self-efficacy to enable children to participate and cost-benefit analysis resulted in lower fidelity [24]. To improve the effects of school-based intervention, collaboration with its wider community and families is required [76]. A teacher participant in Gorely et al. [56] (p. 8) commented, "I think a lot of it is home life; if the parents do not push them towards sporting activities then you are fighting a battle straight away in school." This reinforces that school is only one setting within a broader ecological system in which children operate $[33,77,78]$. In particular, young children are heavily influenced by parental behavior, an influence [41] connected to perceived neighborhood safety $[79,80]$ and parent's self-efficacy in relation to physical activity [24,57]. A multifaceted school-based approach involving different stakeholders generally yields more positive outcomes compared with those that target single components such as school, family, or community [81-84].

There were no studies that intentionally set to adjust the policy level outside of school policy/culture of the socioecological model, although the impact of the educational policy on intervention design and implementation was frequently mentioned at an interpersonal and institutional level. The complexity of policy development, the length of time required to detect perceived impact, and the level of direct influence is not as simple as measuring behavioral change at an individual level [85]. Langille and Rodgers [72] also identified that relatively little research has explored how public policy, community influences, and organizational factors all simultaneously contribute to healthy behaviors among children. Their study identified that school administrators perceived a need for overall direction from the policy level but the responsibility on exactly how to implement physical activity strategies should be determined by the schools. For example, a participating head teacher commented that "the more importance that the government places on a concept the more it will happen" (p. 886). Another noted that "in terms of having that policy, a requirement puts pressure on schools to make sure that we implement it" (p. 886). Policy makers need to recognize that although schools are a means of targeting the vast majority of children, relatively simple interventions at interpersonal or intrapersonal level of the ecological system are unlikely to be effective, as they require some degree of "top down" influence to create a chain reaction across multiple levels [86].

\section{Conclusions}

To date, this is the first realist review of the evidence on school-based physical activity interventions, specifically focusing on children. The synthesis of the evidence highlighted the complex interactions of context, mechanisms, and outcomes at each level of the socioe- 
cological model to provide new insights into what works in school-based physical activity intervention, for whom, under what circumstances, how, and why. The findings have identified intervention features and their implementation that might work in a given context, as well as implementation considerations to promote sustainability. A key message from the evidence synthesis is the recognition of the school environment as part of the bigger societal environment experienced by children and other stakeholders. The findings align with the active school framework proposed by Daley-Smith et al. [13], which identified key stakeholders as school leaders, teachers/other staff, children, parents, and wider stakeholders, and the need to create system change. Further, the conceptual framework could be applied within the active school framework, especially in relation to policy and vision, social and physical environment, and seven opportunities for physical activity that could support decisions to promote sustainable physical activity behavior change for all children within the school context. The validity of a rapid review is questioned by some $[87,88]$; however, there remains a need to achieve a balance between comprehensiveness and timeliness for completing a meaningful evidence synthesis $[89,90]$. The synthesis process generated a large number of initial program theories that demonstrate the complex and multi-level interactions of influences for school-based interventions. Importantly, future research should consider this complexity in relation to intervention design, implementation consideration, evaluation, and analysis plans. The results of this review contribute to knowledge about the multifaceted interactions that influence how physical activity can be enhanced within a school setting given certain contexts. In line with realist philosophy and approaches, the authors encourage future primary research to confirm, refute, and refine the program theories presented [91].

Author Contributions: Conceptualization E.D. and M.J.; methodology, E.D. and M.J.; formal analysis E.D. and M.J., original draft preparation E.D.; writing-review and editing, M.J. All authors have read and agreed to the published version of the manuscript.

Funding: This research received no external funding.

Institutional Review Board Statement: Ethical review and approval were not required for this study, due to using publicly accessible documents and not directly involving humans.

Informed Consent Statement: Not applicable.

Data Availability Statement: Data sharing not applicable.

Conflicts of Interest: The authors declare no conflict of interest.

\section{References}

1. Janssen, I.; LeBlanc, A.G. Systematic review of the health benefits of physical activity and fitness in school-aged children and youth. Int. J. Behav. Nutr. Phys. Act. 2010, 7, 40. [CrossRef] [PubMed]

2. Biddle, S.J.H.; Asare, M. Physical activity and mental health in children and adolescents: A review of reviews. Br. J. Sports Med. 2011, 45, 886-895. [CrossRef] [PubMed]

3. Donnelly, J.E.; Hillman, C.H.; Castelli, D.; Etnier, J.L.; Lee, S.; Tomporowski, P.; Lambourne, K.; Szabo-Reed, A.N. Physical Activity, Fitness, Cognitive Function, and Academic Achievement in Children: A Systematic Review. Med. Sci. Sports Exerc. 2016, 48, 1197-1222. [CrossRef] [PubMed]

4. Bull, F.C.; Al-Ansari, S.S.; Biddle, S.; Borodulin, K.; Buman, M.P.; Cardon, G.; Carty, C.; Chaput, J.-P.; Chastin, S.; Chou, R.; et al. World Health Organization 2020 guidelines on physical activity and sedentary behaviour. Br. J. Sports Med. 2020, 54, 1451-1462. [CrossRef] [PubMed]

5. Sallis, J.F.; Bull, F.; Guthold, R.; Heath, G.W.; Inoue, S.; Kelly, P.; Oyeyemi, A.L.; Perez, L.G.; Richards, J.; Hallal, P.C. Progress in physical activity over the Olympic quadrennium. Lancet 2016, 388, 1325-1336. [CrossRef]

6. Farooq, M.A.; Parkinson, K.N.; Adamson, A.J.; Pearce, M.S.; Reilly, J.K.; Hughes, A.R.; Janssen, X.; Basterfield, L.; Reilly, J.J. Timing of the decline in physical activity in childhood and adolescence: Gateshead Millennium Cohort Study. Br. J. Sports Med. 2018, 52, 1002-1006. [CrossRef]

7. Cooper, A.R.; Goodman, A.; Page, A.S.; Sherar, L.B.; Esliger, D.W.; van Sluijs, E.M.F.; Andersen, L.B.; Anderssen, S.; Cardon, G.; Davey, R.; et al. Objectively measured physical activity and sedentary time in youth: The International children's accelerometry database (ICAD). Int. J. Behav. Nutr. Phys. Act. 2015, 12, 113. [CrossRef] 
8. Jago, R.; Solomon-Moore, E.; Macdonald-Wallis, C.; Sebire, S.J.; Thompson, J.L.; Lawlor, D.A. Change in children's physical activity and sedentary time between Year 1 and Year 4 of primary school in the B-PROACT1V cohort. Int. J. Behav. Nutr. Phys. Act. 2017, 14, 33. [CrossRef]

9. Fox, K.R.; Cooper, A.; McKenna, J. The School and Promotion of Children's Health-Enhancing Physical Activity: Perspectives from the United Kingdom. J. Teach. Phys. Educ. 2004, 23, 338-358. [CrossRef]

10. Story, M.; Nanney, M.S.; Schwartz, M.B. Schools and obesity prevention: Creating school environments and policies to promote healthy eating and physical activity. Milbank Q. 2009, 87, 71-100. [CrossRef]

11. Love, R.; Adams, J.; van Sluijs, E.M.F. Are school-based physical activity interventions effective and equitable? A systematic review and meta-analysis of cluster randomised controlled trials. Lancet 2018, 392, S53. [CrossRef]

12. Jones, M.; Defever, E.; Mackintosh, K.; Letsinger, A. A mixed method systematic review of primary school based interventions to promote physical activity and/or reduce sedentary behaviour. J. Phys. Act. Health 2018, 15, S121. [CrossRef]

13. Daly-Smith, A.; Quarmby, T.; Archbold, V.S.J.; Corrigan, N.; Wilson, D.; Resaland, G.K.; Bartholomew, J.B.; Singh, A.; Tjomsland, H.E.; Sherar, L.B.; et al. Using a multi-stakeholder experience-based design process to co-develop the Creating Active Schools Framework. Int. J. Behav. Nutr. Phys. Act. 2020, 17, 13. [CrossRef] [PubMed]

14. Brown, H.E.; Atkin, A.J.; Panter, J.; Wong, G.; Chinapaw, M.J.; van Sluijs, E.M.F. Family-based interventions to increase physical activity in children: A systematic review, meta-analysis and realist synthesis. Obes. Rev. 2016, 17, 345-360. [CrossRef] [PubMed]

15. Leone, L.; Pesce, C. From delivery to adoption of physical activity guidelines: Realist synthesis. Int. J. Environ. Res. Public Health 2017, 14, 1193. [CrossRef] [PubMed]

16. Naylor, P.J.; McKay, H.A. Prevention in the first place: Schools a setting for action on physical inactivity. Br. J. Sports Med. 2009, 43, 10-13. [CrossRef] [PubMed]

17. Wong, G. Getting to grips with context and complexity-The case for realist approaches. Gac. Sanit. 2018, 32, 109-110. [CrossRef]

18. Pawson, R.; Tilley, N. Realistic Evaluation; Sage: London, UK, 1997.

19. Pawson, R.; Greenhalgh, T.; Harvey, G.; Walshe, K. Realist review: A new method of systematic review designed for complex policy interventions. J. Health Serv. Res. Policy 2005, 10, 21-34. [CrossRef]

20. Rycroft-Malone, J.; McCormack, B.; Hutchinson, A.M.; DeCorby, K.; Bucknall, T.K.; Kent, B.; Schultz, A.; Snelgrove-Clarke, E.; Stetler, C.B.; Titler, M.; et al. Realist synthesis: Illustrating the method for implementation research. Implement. Sci. 2012, 7. [CrossRef]

21. Wong, G.; Greenhalgh, T.; Westhorp, G.; Buckingham, J.; Pawson, R. RAMESES publication standards: Realist syntheses. BMC Med. 2013, 11. [CrossRef]

22. Martin, R.; Murtagh, E. Active Classrooms: A Cluster Randomized Controlled Trial Evaluating the Effects of a Movement Integration Intervention on the Physical Activity Levels of Primary School Children. J. Phys. Act. Health 2017, 14, 290-300. [CrossRef]

23. Magnusson, K.T.; Sigurgeirsson, I.; Sveinsson, T.; Johannsson, E. Assessment of a two-year school-based physical activity intervention among 7-9-year-old children. Int. J. Behav. Nutr. Phys. Act. 2011, 8, 138. [CrossRef]

24. Mendoza, J.A.; Watson, K.; Baranowski, T.; Nicklas, T.A.; Uscanga, D.K.; Hanfling, M.J. The walking school bus and children's physical activity: A pilot cluster randomized controlled trial. Pediatrics 2011, 128, 537. [CrossRef] [PubMed]

25. Gorely, T.; Nevill, M.E.; Morris, J.G.; Stensel, D.J.; Nevill, A. Effect of a school-based intervention to promote healthy lifestyles in 7-11 year old children. Int. J. Behav. Nutr. Phys. Act. 2009, 6, 5. [CrossRef] [PubMed]

26. Eyre, E.L.J.; Cox, V.M.; Birch, S.L.; Duncan, M.J. An integrated curriculum approach to increasing habitual physical activity in deprived South Asian children. Eur. J. Sport Sci. 2016, 16, 381-390. [CrossRef] [PubMed]

27. Beets, M.W.; Okely, A.; Weaver, R.G.; Webster, C.; Lubans, D.; Brusseau, T.; Carson, R.; Cliff, D.P. The theory of expanded, extended, and enhanced opportunities for youth physical activity promotion. Int. J. Behav. Nutr. Phys. Act. 2016, 13, 120. [CrossRef]

28. Huberty, J.L.; Siahpush, M.; Beighle, A.; Fuhrmeister, E.; Silva, P.; Welk, G. Ready for Recess: A Pilot Study to Increase Physical Activity in Elementary School Children. J. Sch. Health 2011, 81, 251-257. [CrossRef]

29. Hyndman, B.P.; Benson, A.C.; Ullah, S.; Telford, A. Evaluating the effects of the Lunchtime Enjoyment Activity and Play (LEAP) school playground intervention on children's quality of life, enjoyment and participation in physical activity. BMC Public Health 2014, 14, 164. [CrossRef]

30. Cohen, K.E.; Morgan, P.J.; Plotnikoff, R.C.; Barnett, L.M.; Lubans, D.R. Improvements in fundamental movement skill competency mediate the effect of the SCORES intervention on physical activity and cardiorespiratory fitness in children. J. Sports Sci. 2015, 33, 1908-1918. [CrossRef]

31. Eather, N.; Morgan, P.J.; Lubans, D.R. Improving the fitness and physical activity levels of primary school children: Results of the Fit-4-Fun group randomized controlled trial. Prev. Med. 2013, 56, 12-19. [CrossRef]

32. Meyer, U.; Schindler, C.; Zahner, L.; Ernst, D.; Hebestreit, H.; van Mechelen, W.; Brunner-La Rocca, H.-P.; Probst-Hensch, N.; Puder, J.J.; Kriemler, S. Long-term effect of a school-based physical activity program (KISS) on fitness and adiposity in children: A cluster-randomized controlled trial. PLoS ONE 2014, 9, e87929. [CrossRef] [PubMed]

33. Van Kann, D.H.H.; Kremers, S.P.J.; de Vries, N.K.; de Vries, S.I.; Jansen, M.W.J. The effect of a school-centered multicomponent intervention on daily physical activity and sedentary behavior in primary school children: The Active Living study. Prev. Med. 2016, 89, 64-69. [CrossRef] [PubMed] 
34. Shearn, K.; Allmark, P.; Piercy, H.; Hirst, J. Building Realist Program Theory for Large Complex and Messy Interventions. Int. J. Qual. Methods 2017, 16, 1-11. [CrossRef]

35. Stame, N. Theory-Based Evaluation and Types of Complexity. Evaluation 2004, 10, 58-76. [CrossRef]

36. Jagosh, J.; Pluye, P.; Wong, G.; Cargo, M.; Salsberg, J.; Bush, P.L.; Herbert, C.P.; Lawrence, W.G.; Greenhalgh, T.; Macaulay, A.C. Critical reflections on realist review: Insights from customizing the methodology to the needs of participatory research assessment. Res. Synth. Methods 2013, 5, 131-141. [CrossRef]

37. Pluye, P.; Gagnon, M.-P.; Griffiths, F.; Johnson-Lafleur, J. A scoring system for appraising mixed methods research, and concomitantly appraising qualitative, quantitative and mixed methods primary studies in Mixed Studies Reviews. Int. J. Nurs. Stud. 2009, 46, 529-546. [CrossRef] [PubMed]

38. Pace, R.; Pluye, P.; Bartlett, G.; Macaulay, A.C.; Salsberg, J.; Jagosh, J.; Seller, R. Testing the reliability and efficiency of the pilot Mixed Methods Appraisal Tool (MMAT) for systematic mixed studies review. Int. J. Nurs. Stud. 2012, 49, 47-53. [CrossRef]

39. Souto, R.Q.; Khanassov, V.; Hong, Q.N.; Bush, P.L.; Vedel, I.; Pluye, P. Systematic mixed studies reviews: Updating results on the reliability and efficiency of the mixed methods appraisal tool. Int. J. Nurs. Stud. 2015, 52, 500-501. [CrossRef]

40. Drummy, C.; Murtagh, E.M.; McKee, D.P.; Breslin, G.; Davison, G.W.; Murphy, M.H. The effect of a classroom activity break on physical activity levels and adiposity in primary school children. J. Paediatr. Child Health 2016, 52, 745-749. [CrossRef]

41. Sallis, J.F.; McKenzie, T.L.; Alcaraz, J.E.; Kolody, B.; Faucette, N.; Hovell, M.F. The effects of a 2-year physical education program (SPARK) on physical activity and fitness in elementary school students. Sports, Play and Active Recreation for Kids. Am. J. Public Health 1997, 87, 1328-1334. [CrossRef]

42. Verstraete, S.J.M.; Cardon, G.M.; De Clercq, D.L.R.; De Bourdeaudhuij, I.M.M. Increasing children's physical activity levels during recess periods in elementary schools: The effects of providing game equipment. Eur. J. Public Health 2006, 16, 415-419. [CrossRef] [PubMed]

43. Dzewaltowski, D.A.; Rosenkranz, R.R.; Geller, K.S.; Coleman, K.J.; Welk, G.J.; Hastmann, T.J. HOP’N after-school project: An obesity prevention randomized controlled trial. Int. J. Behav. Nutr. Phys. Act. 2010, 7, 90. [CrossRef] [PubMed]

44. Efrat, M.W. Exploring Effective Strategies for Increasing the Amount of Moderate-to-Vigorous Physical Activity Children Accumulate During Recess: A Quasi-Experimental Intervention Study. J. Sch. Health 2013, 83, 265-272. [CrossRef] [PubMed]

45. Huberty, J.L.; Beets, M.W.; Beighle, A.; Saint-Maurice, P.F.; Welk, G. Effects of Ready for Recess, An Environmental Intervention, on Physical Activity in Third-Through Sixth-Grade Children. J. Phys. Act. Heal. 2014, 11, 384-395. [CrossRef]

46. Janssen, M.; Twisk, J.W.R.; Toussaint, H.M.; van Mechelen, W.; Verhagen, E.A.L.M. Effectiveness of the PLAYgrounds programme on PA levels during recess in 6-year-old to 12-year-old children. Br. J. Sports Med. 2015, 49, 259-264. [CrossRef] [PubMed]

47. Kang, M.; Brinthaupt, T.M. Effects of Group- and Individual-Based Step Goals on Children's Physical Activity Levels in School. Pediatr. Exerc. Sci. 2009, 21, 148-158. [CrossRef]

48. Mahar, M.T.; Murphy, S.K.; Rowe, D.A.; Golden, J.; Shields, A.T.; Raedeke, T.D. Effects of a Classroom-Based Program on Physical Activity and On-Task Behavior. Med. Sci. Sport. Exerc. 2006, 38, 2086. [CrossRef]

49. Ridgers, N.D.; Stratton, G.; Fairclough, S.J.; Twisk, J.W.R. Long-term effects of a playground markings and physical structures on children's recess physical activity levels. Prev. Med. 2007, 44, 393-397. [CrossRef]

50. Ridgers, N.D.; Fairclough, S.J.; Stratton, G. Twelve-Month Effects of a Playground Intervention on Children's Morning and Lunchtime Recess Physical Activity Levels. J. Phys. Act. Health 2010, 7, 167-175. [CrossRef]

51. Donnelly, J.E.; Greene, J.L.; Gibson, C.A.; Smith, B.K.; Washburn, R.A.; Sullivan, D.K.; DuBose, K.; Mayo, M.S.; Schmelzle, K.H.; Ryan, J.J.; et al. Physical Activity Across the Curriculum (PAAC): A randomized controlled trial to promote physical activity and diminish overweight and obesity in elementary school children. Prev. Med. 2009, 49, 336-341. [CrossRef]

52. Engelen, L.; Bundy, A.C.; Naughton, G.; Simpson, J.M.; Bauman, A.; Ragen, J.; Baur, L.; Wyver, S.; Tranter, P.; Niehues, A.; et al. Increasing physical activity in young primary school children-It's child's play: A cluster randomised controlled trial. Prev. Med. 2013, 56, 319-325. [CrossRef] [PubMed]

53. Kriemler, S.; Zahner, L.; Schindler, C.; Meyer, U.; Hartmann, T.; Hebestreit, H.; Brunner-La Rocca, H.P.; van Mechelen, W.; Puder, J.J. Effect of school based physical activity programme (KISS) on fitness and adiposity in primary schoolchildren: Cluster randomised controlled trial. BMJ 2010, 340, c785. [CrossRef]

54. Burns, R.D.; Brusseau, T.A.; Hannon, J.C. Effect of Comprehensive School Physical Activity Programming on Cardiometabolic Health Markers in Children From Low-Income Schools. J. Phys. Act. Health 2017, 14, 671-676. [CrossRef]

55. Cradock, A.L.; Barrett, J.L.; Carter, J.; McHugh, A.; Sproul, J.; Russo, E.T.; Dao-Tran, P.; Gortmaker, S.L. Impact of the Boston Active School Day Policy to Promote Physical Activity among Children. Am. J. Health Promot. 2014, 28, S54-S64. [CrossRef] [PubMed]

56. Gorely, T.; Morris, J.G.; Musson, H.; Brown, S.; Nevill, A.; Nevill, M.E. Physical activity and body composition outcomes of the GreatFun2Run intervention at 20 month follow-up. Int. J. Behav. Nutr. Phys. Act. 2011, 8, 74. [CrossRef] [PubMed]

57. Moller, N.C.; Tarp, J.; Kamelarczyk, E.F.; Brond, J.C.; Klakk, H.; Wedderkopp, N. Do extra compulsory physical education lessons mean more physically active children-Findings from the childhood health, activity, and motor performance school study Denmark (The CHAMPS-study DK). Int. J. Behav. Nutr. Phys. Act. 2014, 11. [CrossRef] [PubMed]

58. Ridgers, N.D.; Stratton, G.; Fairclough, S.J.; Twisk, J.W.R. Children's physical activity levels during school recess: A quasiexperimental intervention study. Int. J. Behav. Nutr. Phys. Act. 2007, 4, 19. [CrossRef] 
59. Weaver, R.G.; Webster, A.C.; Egan, C.; Campos, C.M.C.; Michael, R.D.; Vazou, S. Partnerships for Active Children in Elementary Schools: Outcomes of a 2-Year Pilot Study to Increase Physical Activity During the School Day. Am. J. Health Promot. 2017, 32, 621-630. [CrossRef]

60. Duncan, S.; McPhee, J.C.; Schluter, P.J.; Zinn, C.; Smith, R.; Schofield, G. Efficacy of a compulsory homework programme for increasing physical activity and healthy eating in children: The healthy homework pilot study. Int. J. Behav. Nutr. Phys. Act. 2011, 8, 127. [CrossRef]

61. Holt, E.; Bartee, T.; Heelan, K. Evaluation of a policy to integrate physical activity into the school day. J. Phys. Act. Health 2013, 10, 480-487. [CrossRef]

62. Oliver, M.; Schofield, G.; McEvoy, E. An Integrated Curriculum Approach to Increasing Habitual Physical Activity in Children: A Feasibility Study. J. Sch. Health 2006, 76, 74-79. [CrossRef] [PubMed]

63. Mcleroy, K.R.; Bibeau, D.L.; Steckler, A.; Glanz, K. An Ecological Perspective on Health Promotion Programs. Health Educ. Behav. 1988, 15, 351-377. [CrossRef] [PubMed]

64. Carver, A.; Watson, B.; Shaw, B.; Hillman, M. A comparison study of children's independent mobility in England and Australia. Child. Geogr. 2013, 11, 461-475. [CrossRef]

65. Faulkner, G.E.J.; Richichi, V.; Buliung, R.N.; Fusco, C.; Moola, F. What's “quickest and easiest"?: Parental decision making about school trip mode. Int. J. Behav. Nutr. Phys. Act. 2010, 7. [CrossRef]

66. Carse, N. Primary teachers as physical education curriculum change agents. Eur. Phys. Educ. Rev. 2015, 21, 309-324. [CrossRef]

67. Martin, R.; Murtagh, E.M. Preliminary findings of Active Classrooms: An intervention to increase physical activity levels of primary school children during class time. Teach. Teach. Educ. 2015, 52, 113-127. [CrossRef]

68. McMullen, J.; Kulinna, P.; Cothran, D. Chapter 5 Physical Activity Opportunities during the School Day: Classroom Teachers' Perceptions of Using Activity Breaks in the Classroom. J. Teach. Phys. Educ. 2014, 33, 511-527. [CrossRef]

69. Morgan, P.J.; Hansen, V. Classroom Teachers' Perceptions of the Impact of Barriers to Teaching Physical Education on the Quality of Physical Education Programs. Res. Q. Exerc. Sport 2008, 79, 506-516. [CrossRef]

70. Pearson, M.; Chilton, R.; Wyatt, K.; Abraham, C.; Ford, T.; Woods, H.B.; Anderson, R. Implementing health promotion programmes in schools: A realist systematic review of research and experience in the United Kingdom. Implement. Sci. 2015, 10, 149. [CrossRef]

71. Owen, N.; Glanz, K.; Sallis, J.F.; Kelder, S.H. Evidence-Based Approaches to Dissemination and Diffusion of Physical Activity Interventions. Am. J. Prev. Med. 2006, 31, 35-44. [CrossRef]

72. Langille, J.-L.D.; Rodgers, W.M. Exploring the Influence of a Social Ecological Model on School-Based Physical Activity. Health Educ. Behav. 2010, 37, 879-894. [CrossRef]

73. Eather, N.; Morgan, P.J.; Lubans, D.R. Social support from teachers mediates physical activity behavior change in children participating in the Fit-4-Fun intervention. Int. J. Behav. Nutr. Phys. Act. 2013, 10. [CrossRef] [PubMed]

74. Bergh, I.H.; van Stralen, M.M.; Grydeland, M.; Bjelland, M.; Lien, N.; Andersen, L.F.; Anderssen, S.A.; Ommundsen, Y. Exploring mediators of accelerometer assessed physical activity in young adolescents in the health in adolescents study-A group randomized controlled trial. BMC Public Health 2012, 12, 814. [CrossRef] [PubMed]

75. O'Connor, T.M.; Jago, R.; Baranowski, T. Engaging Parents to Increase Youth Physical Activity. A Systematic Review. Am. J. Prev. Med. 2009, 37, 141-149. [CrossRef] [PubMed]

76. Ling, J.; King, K.M.; Speck, B.J.; Kim, S.; Wu, D. Preliminary assessment of a school-based healthy lifestyle intervention among rural elementary school children. J. Sch. Health 2014, 84, 247-255. [CrossRef] [PubMed]

77. Pate, R.R.; Davis, M.G.; Robinson, T.N.; Stone, E.J.; McKenzie, T.L.; Young, J.C. Promoting physical activity in children and youth: A leadership role for schools: A scientific statement from the American Heart Association Council on Nutrition, Physical Activity, and Metabolism (Physical Activity Committee) in collaboration with the Co. Circulation 2006, 114, 1214-1224. [CrossRef] [PubMed]

78. Koplan, J.P.; Liverman, C.T.; Kraak, V.I.; Committee on Prevention of Obesity in Children and Youth. Preventing childhood obesity: Health in the balance (executive summary). J. Am. Diet. Assoc. 2005, 105, 131-138. [CrossRef] [PubMed]

79. de Vries, S.I.; Hopman-Rock, M.; Bakker, I.; Hirasing, R.A.; van Mechelen, W. Built environmental correlates of walking and cycling in dutch urban children: Results from the SPACE study. Int. J. Environ. Res. Public Health 2010, 7, 2309-2324. [CrossRef]

80. Carver, A.; Timperio, A.; Crawford, D. Playing it safe: The influence of neighbourhood safety on children's physical activity-A review. Health Place 2008, 14, 217-227. [CrossRef]

81. Heath, G.W.; Parra, D.C.; Sarmiento, O.L.; Andersen, L.B.; Owen, N.; Goenka, S.; Montes, F.; Brownson, R.C. Evidence-based intervention in physical activity: Lessons from around the world. Lancet 2012, 380, 272-281. [CrossRef]

82. Kriemler, S.; Meyer, U.; Martin, E.; van Sluijs, E.M.F.; Andersen, L.B.; Martin, B.W. Effect of school-based interventions on physical activity and fitness in children and adolescents: A review of reviews and systematic update. Br. J. Sports Med. 2011, 45, 923-930. [CrossRef] [PubMed]

83. Brown, T.; Summerbell, C. Systematic review of school-based interventions that focus on changing dietary intake and physical activity levels to prevent childhood obesity: An update to the obesity guidance produced by the National Institute for Health and Clinical Excellence. Obes. Rev. 2009, 10, 110-141. [CrossRef] [PubMed]

84. Salmon, J.; Booth, M.L.; Phongsavan, P.; Murphy, N.; Timperio, A. Promoting physical activity participation among children and adolescents. Epidemiol. Rev. 2007, 29, 144-159. [CrossRef] [PubMed]

85. King, K.M.; Gonzalez, G.B. Increasing physical activity using an ecological model. ACSM's Health Fit. J. 2018, 22, 29-32. [CrossRef] 
86. Kipping, R.R.; Howe, L.D.; Jago, R.; Campbell, R.; Wells, S.; Chittleborough, C.R.; Mytton, J.; Noble, S.M.; Peters, T.J.; Lawlor, D.A. Effect of intervention aimed at increasing physical activity, reducing sedentary behaviour, and increasing fruit and vegetable consumption in children: Active for Life Year 5 (AFLY5) school based cluster randomised controlled trial. BMJ 2014, 348 , g3256. [CrossRef]

87. Ganann, R.; Ciliska, D.; Thomas, H. Expediting systematic reviews: Methods and implications of rapid reviews. Implement. Sci. 2010, 5, 56. [CrossRef]

88. Watt, A.; Cameron, A.; Sturm, L.; Lathlean, T.; Babidge, W.; Blamey, S.; Facey, K.; Hailey, D.; Norderhaug, I.; Maddern, G. Rapid reviews versus full systematic reviews: An inventory of current methods and practice in health technology assessment. Int. J. Technol. Assess. Health Care 2008, 24, 133-139. [CrossRef]

89. Fletcher, A.; Jamal, F.; Moore, G.; Evans, R.E.; Murphy, S.; Bonell, C.P. Realist complex intervention science: Applying realist principles across all phases of the Medical Research Council framework for developing and evaluating complex interventions. Evaluation 2016, 22, 286-303. [CrossRef]

90. Riley, B.; Norman, C.D.; Best, A. Knowledge integration in public health: A rapid review using systems thinking. Evid. Policy 2012, 8, 417-431. [CrossRef]

91. Pawson, R. The Science of Evaluation: A Realist Manifesto; Sage: London, UK, 2013. 